\title{
Sexual Politics and the Interpretation of Nature in Spenser's Two Cantos of Mutabilitie
}

\author{
JENNIFER LAWS
}

\begin{abstract}
I In the Two Cantos of Mutabilitie, the key concept is Nature. For the first time in The Faerie Queene we must meet Nature in person and the narrative is largely taken up with the struggle to achieve supremacy between two of her opposing aspects: Mutability, or the principle of continual decay and change within the universe, and Jupiter, chief god of the heavens, who claims immunity from change. Dame Nature, as the supreme authority in the universe, presides over this debate and pronounces the final judgement. During the trial we come to delight more and more in the various aspects of Nature on earth as well as to admire Dame Nature's wisdom, both in resolving the issue under debate and in understanding her own relationship to eternity.
\end{abstract}

Thus within the poem, Spenser seeks to explore the foundations of life and the meaning of our existence. The role of Nature and her various components is all the more important for mankind if we consider the sixteenth century commonplace view of Nature. In this, Nature comprises not only the landscape and life of this planet, together with the heavenly bodies, but also a part of mankind. The souls of men and women may be considered divine, but their bodies and their "natural" instincts and passions fall within the order of Nature. This view of mankind, poised between the order of Nature and the order of Grace, has been discussed at length by writers such as A. S. P. Woodhouse and C. S. Lewis, ${ }^{1}$ and is one of the assumptions underlying the whole of The Faerie Queene. ${ }^{2}$ The Mutability Cantos are no exception and we see Nature closely linked with the natural world around her and in authority over all "Gods and men" (vi. 35).

Spenser, then, is telling a story that has vital implications for all mankind. As a means of involving his readers even more closely in the narrative and guiding his readers' responses towards the three protagonists and their even- 
tual submission to Almighty God, he introduces sexual politics. That is, he draws on certain assumptions in the reader concerning the roles expected of men and women and the relationship between them, and then either supports these assumptions or refutes them. Interestingly for us in the twentieth century, when sexual roles are once more a burning issue, the result is anything but simplistic. There is no clear-cut division between superior and inferior, such as we find in Milton's Paradise Lost, where Adam is consistently upheld as intellectually and morally above Eve, who is after all but a derivative of her husband and can never achieve the excellence of her origin. Spenser's attitude is more flexible as femaleness for him is far from being inevitably downgrading. And this is in spite of the fact that both poets are dealing with essentially the same problem - how to explain the existence of evil and suffering in the world.

Before looking in detail at sexual politics in the Cantos, I shall glance back at earlier books of The Faerie Queene in order to clarify the complex attitudes that Spenser has, and expects his readers to have, towards male and female roles. Particularly enlightening are the parts played by Britomart and Radigund and their relationship to Artegall. But such warrior women are not the only sort we encounter in the poem. ${ }^{3}$ Frequently, Spenser's female characters are, on the surface, defenceless and weak. And yet even the most traditionally feminine often display an inner fortitude that belies their compliant exterior.

Florimell is an example of a woman who is seemingly helpless, but with an inner strength. Her compelling beauty means that she is at the mercy of all men. Even Arthur interrupts his quest to follow her, not to ravish, but to rescue her from the beastly forester. However, his good intentions are misunderstood by Florimell, who continues to flee in terror from her would-be rescuer (III. iv 48-51). The whole world appears to her to be hostile, and with some cause, for after her escape from the forester, she is threatened first by the witch's son and the spotted beast, then by the old fisherman in the boat, and finally by Proteus. He uses every trick to "winne her liking unto his delight," from impersonating a "Faerie knight" to taking on various "dreadfull shapes" (III. viii. 38-41). But in spite of all these cajolings and threats, Proteus is not successful; Florimell proves to have an inner strength that resists him. Thus the most fearful and defenceless female, through her virtue, can triumph over an aggressive male - with, of course, the help of "the heavens" (viii. 29). Later in Book III the same inner strength is displayed by the gentle Amoret when 
she is tortured by Busirane. It is as though the vulnerability of these women lies not so much within themselves as in the way they are perceived and treated by the male world. Proteus and Busirane assume that they can bend their victims to their wills, and they are enraged when they are foiled. This same assumption of male strength and superiority characterises Jupiter's attitude to the Titaness in the Cantos.

In contrast to Florimell and Amoret, whose strength lies in passive resistance, Britomart is an active figure. From the beginning of Book III, she is presented as one of the greatest knights. With the possible exception of Arthur, her splendour and power are unsurpassed, as she first unseats Guyon (III. i. 6) and then later Artegall (IV. vi. 11). Her reconciliation with Artegall is brought about by a mutual recognition of each other's worth: at the sight of her beauty, Artegall finds his "powrelesse arme benumb"; and when Britomart beholds "the lovely face of Artegall," she too relinquishes her weapon (IV. vi. 21 and 26). Neither one is victorious in battle. This, of course, is partly due to the exigencies of the moral allegory-justice must be tempered by love although not overwhelmed by it. But as readers of Spenser, we know that we do not need to stop at the first obvious interpretation. And along with the ideas on justice and love, Spenser seems to be adding to his explorations of the right relationship between men and women. At other times he has stressed the need for mutual respect and trust. As Britomart exclaims at the very beginning of Book III when she rescues Red Cross from Malecasta's knights, "For soone as maistrie comes, sweet love anone / Taketh his nimble wings and soone away is gone" (i. 25). And although the sentiments and expression are considerably less exalted, the same fundamental idea is present in Satyrane's comment much later in the book:

Extremely mad the man I surely deeme,

That weenes with watch and hard restraint to stay

A womans will, which is disposed to go astray. (III. ix. 6$)^{4}$

Love must be freely given and freely accepted. There is no place for a takeover by one person of another, and so Britomart yields to Artegall even as he yields to her.

Thus it would seem that in their moral worth as soldiers of Christ and at the heart of a sexual relationship Spenser sees his men and women having at least the potential to be equal to one another. But cutting across this ideal are the expectations of a hierarchical society. All creatures have their place within the great chain of being, and just as sons and daughters must obey their parent 
so must women their men. And so when Artegall woos and wins Britomart after their first encounter, she willingly accepts him "for her Lord" and obeys his every wish, even to parting from him so that he can complete his quest (IV. vi. 41-46). Though the inner moral and psychological worth of men and women may be equal, their social status within the family is not. Husband and father must still be head of the household.

These conflicting views on women are further illustrated in Artegall's brush with Radigund. The parallel of Radigund with Britomart is clear: both are splendid fighters and attractive women. Once more Artegall's hand is stayed by the power of feminine beauty (V. v. 12-13). But here the resemblance ends, for whereas Britomart yielded to Artegall as well as he to her, Radigund pursues her advantage and enslaves Artegall. She has thus broken the first rule of true love which must exclude "maisterie." But more than this, she reverses the usual sexual roles within society by forcing Artegall to carry out domestic tasks and by putting "in his hand a distaffe" (v. 23). At this point the poet interrupts the story in his own voice to comment in no uncertain terms on this disgraceful affair:

Such is the crueltie of womenkynd,

When they have shaken off the shamefast band,

With which wise Nature did them strongly bynd,

T'obay the heasts of mans well ruling hand,

That then all rule and reason they withstand,

To purchase a licentious libertie.

But vertuous women wisely understand,

That they were borne to base humilitie,

Unlesse the heaven them lift to lawfull soveraintie.

(V. v. 25)

This stanza presents considerable difficulty for the reader. In one sense we can see that the main idea is consistent with Britomart's submission to Arthur - women are below their husband in status and must obey them; but in another sense the stanza shocks us. It seems to go beyond the personal relationship and insist that women by "Nature" are inferior to men. After the splendid images of the power and glory of such women as Belphoebe and Britomart in Books III and IV, we balk at such a suggestion. Their greatness seems to reside in their own inherent virtue and worth, not in any special dispensation from heaven as the last line of the above stanza implies. Even Radigund is not criticised for being a famous warrior, but only for her subjugation of Artegall. We can only conclude that in Book V, which focusses 
on the need for law and order in society, the hierarchical view of men and women is uppermost, and at this point in the narrative temporarily obscures more tolerant attitudes.

The ninth line of the stanza quoted above seems to indicate that Spenser himself felt the danger of his doctrinaire views - hence the necessary let-out, should the queen be offended. The whole Radigund episode, with the mingling of moral and political issues, highlights the ambivalence towards women that is clearly present in Spenser's mind and in the minds of his contemporaries. Elizabeth herself provided an example of a dazzlingly successful woman who epitomised all the growing pride in being English, and yet felt it necessary to apologise for having "the body but of a weak and feeble woman." Moreover, in spite of the need for an heir, she remained single and so kept a greater measure of independence.

Thus in the first six books of The Faerie Queene, Spenser presents a multiplicity of views on the roles of men and women. We find the patriarchal assumption that strong is equal to male and weak to female; and yet even within this framework, we have seen women display a fortitude and resistance which is anything but feeble. At the other extreme we have witnessed female warriors who challenge all the usual assumptions about female inferiority. But ultimately even the most powerful woman must submit to the authority of her lover or husband. These varied attitudes are found in the Cantos where they are used to guide our responses to the narration. Our perception of Mutability, Jupiter and Dame Nature gradually changes as Spenser exploits the complexity of sexual politics. The struggle for power in the universe is revealed through the struggle for power between the sexes.

The Cantos begin by introducing the conflict between the Titaness, otherwise called Mutability, and "all the Gods." At first it appears to be a straightforward case of evil trying to overtake good. The Titaness comes from the race of giants which Spenser has mentioned many times before in The Faerie Queene - and always pejoratively. ${ }^{6}$ This aspect is strengthened here by reference to two female Titans: Hecate, associated with black magic, and Bellona, the goddess of war. Mutability is thus associated with disruption, violence and evil in the female sex. In addition we learn that she has changed all "earthly things" and altered "all the worlds faire frame" (vi. 5). Moreover, the Titaness has attacked not only the physical universe but also human society: 
Ne shee the lawes of Nature onely brake,

But eke of Justice and of Policie;

And wrong of right, and bad of good did make,

And death for life exchanged foolishlie:

Since which, all living wights have learn'd to die,

And all this world is woxen daily worse.

O piteous worke of MUTABILITIE!

By which, we all are subject to that curse,

And death in stead of life have sucked from our Nurse.

(vi. 6)

Here, Spenser, as well as defining Mutability, has juxtaposed her disruptive force with the life-giving of Nature. Both concepts are personified as females: Mutability, as we have seen, through the Titaness, and Nature through the word "Nurse" and the idea of suckling. At this early stage of the poem, then, any temptation to regard all femaleness as a blot on creation has been countered, for the female sex has been used to express both the nadir and zenith of existence.

And now the action proper begins as Spenser turns from general principles to the bid that Mutability makes for the heavens and even for the seat of Jove himself. The significance of the gods and goddesses who rule heaven is not obvious at first, but it would seem that they represent the eternal principles of life. Their close connection with our world is evident as any movement in heaven, such as the ensuing fight between the Titaness and the moon goddess, or the action of Jupiter shaking his locks, profoundly affects the earth (vi. 14 and 30). And yet they are not subject to the same mutability. They appear as relatively constant; even Cynthia, the moon goddess, who is usually a symbol of inconstancy, reigns in "everlasting glory" (vi. 8). It looks as though the heavenly powers not only rule the sky, but are guardians of the continuity of created Nature on earth. ${ }^{7}$

The stage is set for a mighty contest and we, as mortals, must tremble at the possibilities. Our sympathies are on the side of Jupiter, for not only does the Titaness appear to represent all that is evil and threatening, but Jupiter is upheld as all that is glorious and right. He is supreme, as the constant repetition of the word "high" and its associates implies. At the beginning we hear of the "Great power of Jove, and high authority" (vi. 3); the moon goddess only reigns because "highest Jove" has ordained it (vi. 12); his own palace is "fixt in heavens hight" (vi. 15); and in stanza 17 he is again "high Jove". He is also referred to as the "father of the Gods" (vi. 15), a phrase which reminds us of the Christian term "God the Father," just as the use of the name "Jove" connects him 
with Jehovah of the old Testament. As the consultation with the other heavenly powers begins, we are suitably awed at the appearance of this mighty being:

His black eye-brow, whose doomefull dreaded beck

Is wont to wield the world unto his vow,

And even the highest Powers of heaven to check (vi. 22)

What possible chance can the Titaness have against such an adversary with her ill-considered "hot bold emprize"? As she "boldly" approaches Jupiter, we still see him in all his glory, utterly "feareless" and "full of grace and Majestie" (vi.24). He is so sure of himself that he graciously asks the Titaness to explain her mission to him, addressing her patronisingly as "thou fraile women" (vi. 25).

But now there begins a change in the reader's perception of the two protagonists. This is brought about by a shift in the point of view, which operates in two ways. In the first instance, the narrator shows us the Titaness in a new light so that she begins to gain our sympathy. Her rash boldness becomes very real courage as we see her "inly quaking" before the mighty god (vi. 25), but determined to persist:

Shee halfe confused with his great commaund,

Yet gathering spirit of her natures pride,

Him boldly answer'd thus to his demaund. (vi. 26)

And then the narrator not only makes us aware of Mutability's courage, but for the first time portrays her as an attractive person. Before this she has been referred to as just a woman, or the Titaness, or even less favourably as "the Giantesse"(vi. 13), but at this point we learn that all present wonder at her beauty:

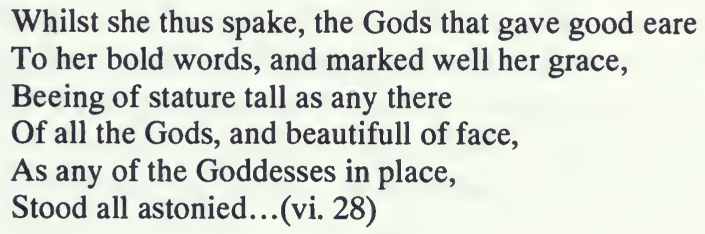

But equally as telling as the shift in the narrator's point of view is the change in the speaker, for now we hear the Titaness in her own voice challenging Jupiter. Previously, in her arguments with Cynthia and Mercury, her words were only indirectly reported (vi. 11 and 18). But as she begins to put forward 
her case to the assembly of gods, she gradually wins our support. The exaggerated picture of Jupiter's glory begins to crack and we are reminded of some very disagreeable facts about the king of the gods, notably his mode of accession to the throne, first through the treachery of his father, Saturn, towards his brother, Titan, and then through his own "might" (vi. 27). Thus the Titaness has become, in our eyes, a worthy adversary of Jupiter, both in her striking appearance and in the moral worth of her courageous behaviour and apparently rightful claim to the throne.

The reader now views Jupiter with a certain suspicion. We are no longer completely convinced by his posturings, and an ironic distancing creeps into our response to him when he begins to bluster and threaten. First he refers to the disastrous consequences of past rebellious behaviour, and then he uses personal abuse to belittle the Titaness, calling her "off-scum of that cursed fry" (vi. 30). His ensuing thunder and lightning, while bringing "terror" to all the universe, is beginning to be less impressive to us, especially when it abruptly ceases because he catches sight of the beauty of the Titaness. Jupiter now reminds us less of the infallible god and more of the distinctly sexual being who in many legends has descended to earth and forced his will on various females. Not that he is about to ravish the Titaness, but he does succumb to her feminine charms as "when he looked on her lovely face / ... He staide his hand (vi. 31). The parallel with the human weakness of Artegall is unmistakable. The only way Jupiter can defend his title is to reiterate what the Titaness has already said about conquest, and merely add the supposed hand of Fate:

For, we by Conquest of our soveraine might,

And by eternall doome of Fates decree,

Have wonne the Empire of the Heavens bright. (vi. 33)

And then once more he uses his masculine superiority to downgrade the Titaness by calling for her to "ceasse they idle claime thou foolish gerle" (vi. 34).

By this stage, Mutability appears to be anything but a foolish girl, for she has called to account the great god and made him bend before her charms. Now she has the sense to go beyond him and appeal to the higher power of Nature, much to the chagrin of Jupiter, who "Did inly grudge" (vi. 35). He is indeed not behaving in a very divine manner.

Thus Spenser has used role expectations first to enhance the power and authority of the male Jupiter over his foolish, female opposition; and then by a change in the point of view to undermine that same male authority so that 
it appears aggressive and patronising as well as humanly frail. The Titaness, meanwhile, has risen from a position of inferiority to one of equality in grace and beauty (if not strength) and possible superiority in courage and integrity. Spenser's ambivalent attitude towards women enables this transition to take place, for in the first instance he draws on the patriarchal view that sees the female as innately weaker than the male, especially in a personal relationship, and then when the debate turns to public affairs, the female assumes equality with her opponent. The Titaness has the courage to reject Jupiter's insistence on himself as the male authority and on herself as the girl child, and demand that she be taken seriously in the affairs of one of Spenser's warrior women. ${ }^{8}$

The effect of this alteration in the balance of power is twofold. First, it creates an interesting story as we watch the changing relationship between Jupiter and Mutability so that at the point when the whole business is turned over to a higher authority, we are in a state of uncertainty. In other words an element of true suspense has entered the narrative, for we are not at all sure what the judgement will be. Secondly, it affects our view of Nature. By showing us that the great god Jupiter is flawed, Spenser makes us accept that beyond him is an even greater power to whom Mutability can turn for justice. This power is "the highest him, that is behight / Father of gods and men by equal might, / To weet, the God of Nature" (vi. 35). In addition to this downgrading of Jupiter, the comparable upgrading of the Titaness contributes even further to the glorification of Nature, for Mutability is but an aspect of Nature, as we shall see more clearly in the next canto.

Meanwhile the reference to Nature as a male god merits some discussion. According to the usual tradition, we expect Nature to be the familiar "dame" or "mother," and Spenser himself referred to her as our "Nurse" earlier in the poem (vi. 6). The change of sex is, therefore, surprising, but it is also extremely effective. How different our response would be if at this point in the poem, Nature were to be described as the "mother" of the gods. Ultimate power, especially in family relationships, is still (at least in Spenser's time) vested in the male, however much we are led to believe in the possibility of female honour and glory. As a symbol of the highest authority, it is appropriate that Nature should be a father, even in defiance of the more usual tradition. ${ }^{9}$

There are other important effects of Nature's change in sex. The first and most significant is that it begins a new line of thought, one which is realised more fully at the end of the poem: Nature transcends gender; whether she is male or female is of little account. The great god-or goddess - is above the kind of sexual politics we have witnessed between Jupiter and Mutability. 
And secondly the element of suspense is increased as we wait with even greater interest for the outcome of the trial when the judgement is to be pronounced by such an enigmatic being.

The digression on Dan Faunus that occupies the rest of canto vi prolongs the suspense, but, as we might expect, it does a great deal more. We descend from the heaven and see Mutability at work on earth in the destruction of the natural beauty around Arlo. And in the light-hearted, amusing story about the presumption of Faunus in wanting to spy on Diana, we enjoy a parody on the presumption of the Titaness in her bid for the heavens. But even more interesting parallels and contrasts to the main story emerge if we consider carefully some of the details, particularly those relating to gender. In the Faunus story the male and female roles are reversed. The reigning deity is the goddess Diana, and Faunus is the "Foolish God" (vi. 42). And this male Faunus acts in a way that by tradition belongs to the female: he is counted amongst the "babblers" who cannot control their giggling (vi. 46); and he tempts Molanna to betray her mistress Diana with "Queene apples and red cherries" (vi. 43). There is a hint of Eve's apple here and the cherries remind us of the cherry lips that are traditionally offered by the female as a temptation. At the end of the story, the usual male dominance over the female victim is completely reversed. First Faunus is mocked and scorned and made to appear utterly ridiculous like a "Mome"; then he is threatened with being "gelt" or castrated; and finally he is dressed in a "Deares skin" and mercilessly hunted by Diana and her nymphs (vi. 49-52). The female revenge on male presumption is no laughing matter, and certainly no more to be commended than the male chauvinism of Jupiter.

The harshness of the ridicule heightens the sense of parody so that the sin of presumption exhibited by the Titaness is now more fully realised. It is a timely reminder of her essential wrong-headedness, just when we had begun to think that she might have a certain amount of right on her side. But because the ridicule stems largely from the reversal of the usual male and female roles, it goes beyond a parody of the Titaness and works on our whole perception of gender. We begin to feel an absurdity in the difference we expect of men and women. In fact, the story of Faunus makes a mockery of the kind of sexual politics we have seen inaction between Jupiter and Mutability. I am not suggesting that Spenser is rejecting the idea of sexual hierarchy, but he is, I believe, satirising role expectations for a particular purpose in this poem beyond that of entertaining us.

That purpose has already been hinted at in Mutability's reference to Nature as a male god. Now, at the beginning of canto vii, when Nature takes 
up her position as presiding judge, she is the more familiar "Dame", but her sexual ambiguity continues:
Yet certes by her face and physnomy,
Whether she man or women inly were, That could not any creature well descry:
For, with a veile that wimpled every where,
Her head and face was hid, that mote to none appeare.
(vii. 5)

This sexual ambiguity is part of Nature's all-inclusive property. She contains within her both male and female, just as she combines all opposites and is "ever young and full of eld, / Still moving, yet unmoved from her sted; / Unseene of any, yet of all beheld "(vii. 13). The absurdity of role differences in the Faunus story, by their very contrast, serves to make even more splendid the great goddess of Nature who transcends all differences. Rather gender, with its ever shifting expectations, becomes associated with the changes of Mutability. Spenser has used the hermaphrodite image before in the figure of the veiled Venus who has "Both male and female, both under one name" (IV. x. 41). Edgar Wind connects this hermaphrodite Venus with the Neoplatonic idea of the many infolded in the one, the one signifying the divine. ${ }^{10}$ But whatever its precise source, Spenser's image of the two sexes in one is clearly meant to indicate the sublime and mysterious qualities of the goddesses, whether Venus or Nature, as compared to inferior beings who are limited to one sex or another.

And yet paradoxically, in spite of the fact that Nature is above gender differences, she is portrayed throughout the trial as a sexual being, which indeed she must be if she is to represent all life. Her first appearance is heralded by the magnificent line that twice insists on her female sex: "Then forth issewed (great goddesse) great dame Nature" (vii. 5). And Spenser exploits this femaleness to the full, for it enables him to present convincingly Nature's beauty and fertility as well as her love for all creation. She is associated with the sensuous delights of flowers growing beneath her feet: "Tenne thousand mores of sundry sent and hew, / That might delight the smell, or please the view" (vii. 10). And through the river Mole, new growth and love attend her:

And Mole himselfe, to honour her the more,

Did deck himself in freshest faire attire,

And his high head, that seemeth alwaies hore 
With hardened frosts of former winters ire, He with an Oaken girlond now did tire, As if the love of some new Nymph late seene, Had in him kindled youthfull fresh desire, And made him change his gray attire to greene; Ah gentle Mole! such joyance hath thee well beseene. (vii. 11)

A little further on, Nature is again presented to us as the source of all life and its protector in the reference to her as "This great Grandmother of all creatures bred" (vii. 13).

This view of Nature as life-giving and joyous is continued during the trial when the activities of Mutability on earth gradually become more and more identifiable with those of Nature herself. The words of Mutability on the four elements of earth, air, water and fire, and their proclivity to change, are succeeded by a pageant called up by Nature. And during this we almost forget the theme of mutability, for although change is present in the succession of the seasons and the months, the qualities stressed are those of vitality and delight. Mutability has become indistinguishable from life itself. The procession may, in fact, end with Death, but the poet returns to Life and his youth and beauty:
But Life was like a faire young lusty boy,
Such as they faine Dan Cupid to have beene,
Full of delightful health and lively joy,
Deckt all with flowres, and wings of gold fit to employ.
(vii. 46)

Thus we come to the logical conclusion of Mutability's gradual rise in status during the first part of the Cantos. From being responsible for all our woe, for "death in stead of life" (vi. 6), Mutability has come to represent all that is most delightful in life, and appears synonymous with Nature herself. This, in turn, adds further to the splendour of Nature, for the glorious pageant of life, supposedly there to convince us of Mutability's power, contributes imaginatively to our awareness of the richness of Nature on earth.

But although Mutability's fair face seems close to Nature, she is not completely identifiable with her. Not only is Mutability responsible for death and suffering in the world, but she lacks the close association of Nature with the divine. As we learn at the beginning of the poem, Mutability "alter'd quite" the life which "Nature had establisht first" and which "God had blest" (vi. 5). 
When Nature appears in person at the trial, we see even more clearly her closeness to God, for the poet in his own voice tells us that he was as dazzled by Nature's garments

As those three sacred Saints, though else most wise,

Yet on mount Thabor quite their wits forgat,

When they their glorious Lord in strange disguise

Transfigur'd sawe; his garments so did daze their eyes.

(vii. 7)

The effect of this image is complex, for the direct comparison of Nature to Jesus adds to the glorification of Nature, while at the same time it reminds us that beyond her there is Christ and Almighty God.

The subordination of Nature to God is made clearer in the last words of the poem:

But thence-forth all shall rest eternally

With Him that is the God of Sabbaoth hight:

O that great Sabbaoth God, grant me that Sabbaoths sight.

God is the ultimate being and Nature, who was formerly "the highest him," must give way to an even higher power. It is possible that just as the poet hopes to share in eternity, so will all Nature, but it seems that it will not be in her usual earthly form. As the goddess herself says, there will come a time when "all shall changed bee" and then "none no more change shall see" (vii. 59). In her wisdom, Nature foresees her own transcendence by the divine and a different order established in eternity. One thing is certain: Mutability will no longer exist. If Nature shares in eternity it will be in her original, pristine form before the ravages of the Titaness.

At this point in the poem, Spenser uses the traditional sexual hierarchy to underline Nature's subordination to Almighty God. It is indeed fitting that here she continues to be the familiar dame or goddess, for, like many of Spenser's women, Nature can be beautiful, wise, virtuous and full of divine grace, but in the end she must accept her lord and master.

There are two conclusions I want to draw from this study of the Mutability Cantos. One is the consummate skill with which Spenser uses gender and role expectations to define Nature and her relationship to God. From the struggle for power in the universe between Jupiter and Mutability through to the 
portrayal of Dame Nature as male, hermophrodite and female, the poem never falters in its purpose. Each part contributes to the whole so that even the digression on Faunus, with its satire on sexual roles and the attendant absurdities, highlights the sublimity of Nature in transcending gender differences.

The other point to be made relates to the complexity of Spenser's views on male and female roles. The masculine may represent the ultimate authority, but there are times when this notion is challenged and we realise in Jupiter how easily power can be abused and how false the assumption of male superiority can be. On the other hand, while Spenser frequently seems to have a special empathy with women (in the Cantos as in other parts of The Faerie Queene), he does not sanctify the feminine principle to the extent that it becomes the "most tangible hope to which human nature can reach," as Stevie Davies claims. ${ }^{11}$ For Spenser, the feminine is only a part of the all-embracing concept of Nature. And it is Nature's glory that the Cantos of Mutabilitie celebrate.

\section{University of Otago}

\section{Notes}

1. See C. S. Lewis, Studies in Words (Cambridge: Cambridge University Press, 1960), Chapter 2; C. S. Lewis, The Discarded Image (Cambridge: Cambridge University Press, 1964), Chapter 7; and A. S. P. Woodhouse, "Nature and Grace in The Faerie Queene," ELH, xvi (1949), 194-228.

2. For the most explicit example of this assumption see the Garden of Adonis, where the natural setting ("So faire a place, as Nature can devize") provides the nurturing for Amoret, the symbol of human sexual love (III. vi. 29-53).

3. The phrase "warrior women" is taken from Simon Shepherd, Amazons and Warrior Women: Varieties of Feminism in Seventeenth Century Drama (Brighton: The Harvester Press, 1981). Although this books deals mainly with later drama, the first two chapters explore feminism in The Faerie Queene with particular reference to Britomart and Radigund.

4. All quotations from The Faerie Queene in this paper are taken from Spenser: The Faerie Queene, edited by A. C. Hamilton (New York: Longman, 1977).

5. From the Queen's speech to the troops at Tilbury in 1588 from George Ballard, Memoirs of Several Ladies of Great Britain, edited by Ruth Perry (Detroit: Wayne State University Press, 1985), p. 224.

6. For two of the most extended references to the Titans, see III. vii. 47, and VI. vii. 41.

7. The significance of these planetary deities becomes clearer at the end of the poem when it is because Mutability is not responsible for the perpetual ordered renewal of life on 
earth that Jupiter is allowed to continue his reign. See Nature's judgement when she states that all things "are not changed from their first estate; / But by their change their being doe dilate" (vii. 58).

8. We might well remember Belphoebe's sharp rejection (with a javelin) of Braggadocchio's insistence on her as a frail woman fit only for a life of ease at court and as an object for his lust (II. iii. 39-42.

9. The depiction of Nature as a father is not new. E. R. Curtius points out that as early as the tenth Orphic hymn, Nature was portrayed not only as "the age-old Mother of us all," but also as "father." See E. R. Curtius, European Literature in the Latin Middle Ages, translated by Willard R. Trask (London: Routledge and Kegan Paul, 1953), pp. 106-107.

10. Edgar Wind, Pagan Mysteries in the Renaissance (London: Faber and Faber, 1958), pp. 172-174.

11. Stevie Davies, The Idea of Woman in Renaissance Literature: The Feminine Reclaimed (Brighton: The Harvester Press), p. 21 